\title{
A Methodology for Cleaner Production Implementation at a University Campus in Lima, Peru
}

\author{
Johnny Nahui-Ortiz, Ph.D. ${ }^{1}$, Alejandro Mendoza, MSc. ${ }^{2}$, Freddy Sotelo, Dr. ${ }^{3}$ \\ ${ }^{1}$ National University of Engineering, Peru, jnahui@meningenieros.com \\ ${ }^{2}$ National University of Engineering, Peru, amen807@hotmail.com \\ ${ }^{3}$ National University of Engineering, Peru, fresov@uni.edu.pe
}

\begin{abstract}
The main objective of the current study is to propose a methodology for implementation of a Cleaner Production program at the campus of the National University of Engineering in Lima, Peru.

Documentation review was carried out with regard to principles and applications of Cleaner Production, identifying strategies associated with its implementation in processes, products, and services.

A university campus was characterized, being the target of the present study, as a mix of processes with entries, operations, and outputs related to the distinct schools and departments. Relevant usages and consumptions of electricity, fuels, water, and paper were identified among others. Also, guidelines for further recollection of quantitative data as well as the unit costs of their utilization were established.

A methodology for implementation of a Cleaner Production program at a university campus was elaborated on the basis of five general steps: 1) Planning and Organization, 2) Diagnostic, 3) Feasibility Study, 4) Implementation and Monitoring, and 5) Continuous Improvement.
\end{abstract}

Keywords- Cleaner production, University campus, Processes and Services, Eco-efficiency, Improvement Opportunities

\section{INTRODUCTION}

Cleaner production is the continuous application of a preventive and integrated environmental strategy for processes, products, and services with the aim of improving overall efficiency for the organization and reducing risks for human population and the environment. It might be applied to processes that are used in any organization, for several products and services offered within the society.

In productive processes, it results from one or a combination of the following:

- Raw materials, water, and energy conservation and savings, among other inputs.

- Elimination of raw materials and both toxic and dangerous inputs through substitution, with the aim of reducing negative inputs that come along with their extraction, storage, usage, and transformation.

- Reduction at the source of quantity and toxicity of total emissions and waste during productive processes.

Digital Object Identifier (DOI):

http://dx.doi.org/10.18687/LACCEI2019.1.1.459

ISBN: 978-0-9993443-6-1 ISSN: 2414-6390
In products, it targets:

- Reduction of product impact for the environment, health and safety during its life cycle, from raw material extraction, its manufacturing and use, up to its final disposal.

In services, it targets:

- Incorporation of environmental considerations for the design and delivery of the service.

It should be noted that originally Cleaner "Production" was mainly oriented to organizations dedicated to productive processes; however, nowadays it is also applied to organizations dedicated to delivering services, as it is the case of a university campus.

\section{Cleaner Production Strategies}

Cleaner production strategies include: Operational good practices, Better control of processes, On-site re-utilization, recovery, and recycling, Production of useful by-products, Substitution of raw materials, Reformulation and redesign of a product, Equipment modification, and Technology change.

Operational good practices include organization procedures and methods, management practices, waste segregation, better handling of materials, production schedule, inventory control, and training.

Better control of processes includes equipment operational procedures and instructions written in a clear way and available in such a way that processes are more efficiently executed and both waste and emissions are less produced. It also includes registration of operations in order to verify compliance with processes specifications.

On-site re-utilization, recovery, and recycling include reutilization of waste materials within the same process for other application as a benefit for the organization.

Production of useful by-products includes transformation of a waste into a by-product that might be sold as a raw material for organizations in different sectors of the business.

Raw material substitution includes less toxic inputs, renewable materials, auxiliary materials that have longer life cycle in storage cabinets.

$17^{\text {th }}$ LACCEI International Multi-Conference for Engineering, Education, and Technology: "Industry, Innovation, And Infrastructure for Sustainable Cities and Communities", 24-26 July 2019, Jamaica. 
Product reformulation and redesign include designs with less environmental impact during product life cycle, designs with less environmental impact during its production, and increment of product life cycle.

Equipment modification includes better equipment, better operational conditions, production equipment and facilities in such a way that processes might be carried out more efficiently and both waste and emissions might be less produced.

Technology change includes technological update in the organization, more automation, better operational conditions and processes re-engineering.

\section{APPLIED METHODOLOGY}

The applied methodology consists of a document revision in order to establish a general analytical framework for Cleaner Production. On the basis of such analytical framework, systems characteristics to be analyzed are established. In this case, the system is a university campus.

The system considered for the present study consists of facilities inherent to activities to be carried out within a university campus, such class rooms, administrative offices, laboratories, rest rooms, and others. Within such system, it has been observed the use of several inputs, such electricity, fuels, water, and paper among others.

System description is carried out up to the level in which usage and consumption of inputs related to each area might be identified, considering common characteristics and distinctive aspects.

After characterizing the system under a cleaner production approach, it is established a basis for later evaluation of cost associated with the use and consumption of identified inputs. Such evaluation becomes decisive for later proposal of improvements related to Cleaner Production which will be based on the economic profitability of a cost-benefit type.

Last but not least, criteria to be considered for identification and proposal of cleaner production measures are established, as a part of an integral program that might be applied to a university campus within the scope of continuous improvement.

In that sense, the working methodology to be followed in the current study falls within the framework of the directions included in the Peruvian standard GP 900.200. Also, International Standard ISO 50001, that aims to promote energy savings and carbon emissions reduction in organizations, can effectively contribute to cleaner production measures.

\section{STUDY RESULTS}

The methodology to be followed in order to implement a Cleaner Production program in a university campus consists of five general steps: 1) Planning and Organization, 2) Cleaner Production Diagnostic, 3) Feasibility Study, 4) Implementation and Follow-Up, and 5) Continuous Improvement.

\section{A. First Step: Planning and Organization}

It is decisive to involve and obtain the commitment of authorities at the university campus. This implies to make available materials, human, and financial resources in order to achieve target objectives. With regard to that, authorities should be informed about the benefits that can be obtained through a Cleaner Production program.

At this stage, authorities' role has been stated, a Cleaner Production committee has been established and its leader has clear functions, general objectives have been defined, a schedule for activities has been elaborated, limitations and alternative solutions are identified

\section{B. Second Step: Cleaner Production Diagnostic}

It is quite important to carry out a diagnostic in order to develop technical and financial foundations for the program. In general, it is conducted by an external consulting team, who are experts in Cleaner Production, in the fields of energy savings and pollution prevention, and it is supported by a Cleaner Production committee.

At this stage, information about processes and services are gathered. Information gathering takes into account size, nature and complexity of a university campus. A diagnostic should follow the services that the university campus provides from the beginning to the end, focusing on areas wherein products, by-products, waste, emissions, and effluents are generated.

\section{Third Step: Feasibility Study}

For each one of the opportunities selected during the diagnostic, it should be determined the required evaluation (technical, economic, and/or environmental) in order to make a decision about its feasibility, and the depth in which the required evaluations will be carried out.

At this stage, the impact that opportunities will have on service efficacy, operation time, addition or elimination of an operation or activity, additional training and/or personal change should be considered. The goal is to determine whether the opportunities to be implemented are profitable for a university campus. Carrying out such analysis is key, otherwise the opportunity may lead to an economic failure of the project which would discourage other investments in this area.

\section{Fourth Step: Implementation and Follow-Up}

In order to assure that implementation of the opportunities might be carried out in a logical and a programmed way, a detailed action plan should be prepared.

At this stage, a detailed action plan is prepared, Cleaner Production opportunities are implemented including supervision and evaluation. A report will be prepared for the

$17^{\text {th }}$ LACCEI International Multi-Conference for Engineering, Education, and Technology: "Industry, Innovation, And 
university campus with information about improvements and disadvantages as a result of the implementation.

\section{E. Fifth Step: Continuous Improvement}

Cleaner Production philosophy is considered as a continuous improvement program that has as a primary objective to reduce constantly emissions, waste, effluents, raw material and energy consumption in the university campus.

Next, the proposed methodology is shown in a graphical form in Figure 1.

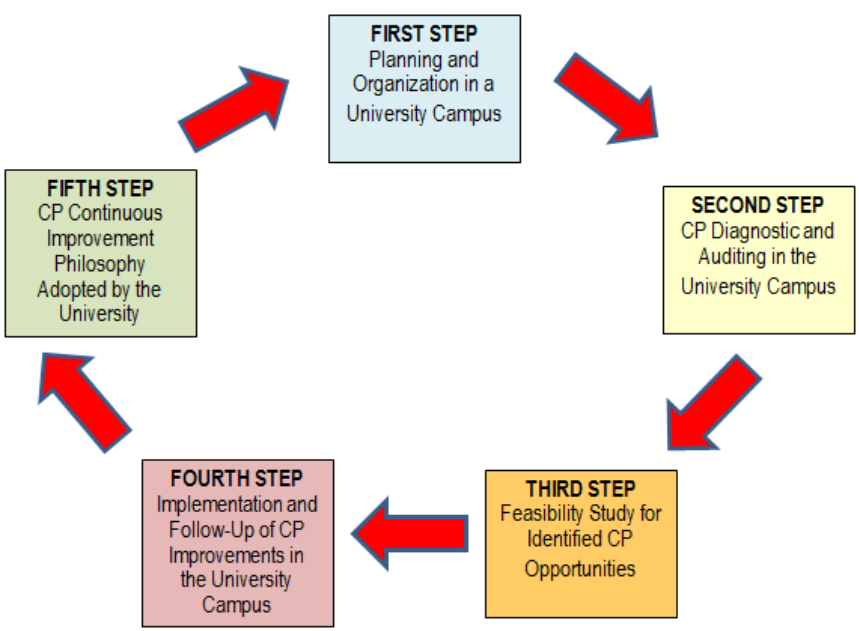

Fig.1. Cleaner Production (CP) methodology for a university campus.

In Figure 2, a sample of data for a specific office area in the university campus is shown. The main idea is to describe what items are located in that area and how those items participate in the consumption of electricity, paper, and other inputs.

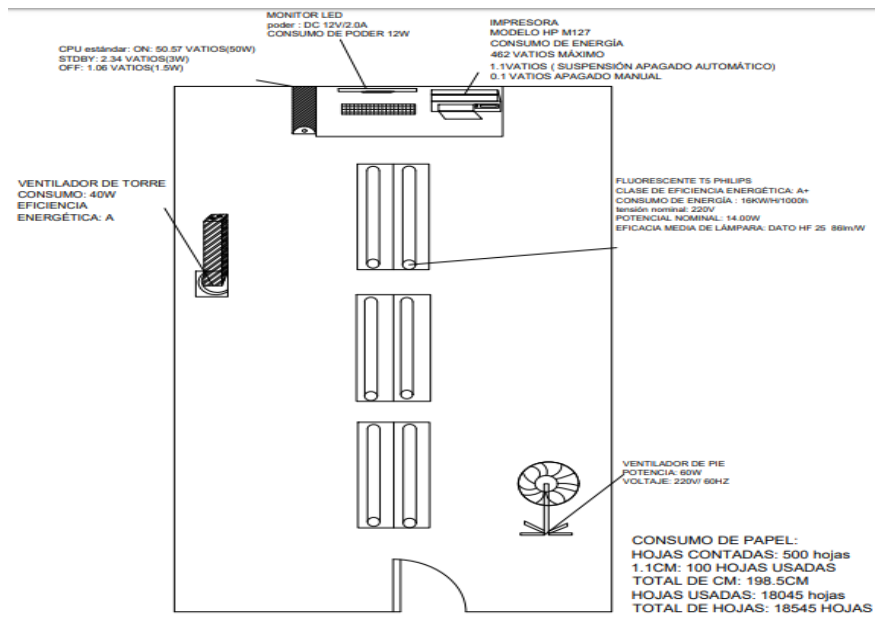

Fig.2. Sample of data for a specific office area in the university campus.
In Table I, a sample of energy consumption data for a specific office area is shown. The main idea is to establish what is the electrical power required by each equipment or artefact and for how long they operate.

TABLE I

SAMPLE OF ENERGY CONSUMPTION DATA FOR A SPECIFIC OFFICE AREA

\begin{tabular}{|c|c|c|c|}
\hline $\begin{array}{c}\text { ITEM } \\
\text { NUMBER }\end{array}$ & DESCRIPTION & POWER (W) & OPERATION (HR) \\
\hline 1 & PC DESKTOP CPU & 50 & 2 \\
\hline 1 & PC LED SCREEN & 12 & 2 \\
\hline 1 & PRINTER HPM127 & 462 & 2 \\
\hline 6 & FLUORECENT LAMP T5 & 14 & $\mathbf{8}$ \\
\hline 1 & STANDING FAN & 60 & 3,5 \\
\hline 1 & TOWER-TYPE FAN & 40 & 3,5 \\
\hline
\end{tabular}

In Table II, a sample of unit cost for energy consumption and power demand is shown. The main idea is to highlight the complexity associated with the electricity tariff that is applied for determination of electricity bill in a university campus, considering energy consumption and power demand charges.

TABLE II

SAMPLE OF UNIT COST FOR ENERGY CONSUMPTION AND POWER DEMAND

\begin{tabular}{|c|c|c|}
\hline \multirow{2}{*}{\multicolumn{3}{|c|}{ TARIFA CON DOBLE MEDICIÓN DE ENERGIA ACTIVA Y }} \\
\hline & & \\
\hline Cargo Fijo Mensual & $\mathrm{S} / \mathrm{dmes}$ & 3.65 \\
\hline Cargo por Energia Activa en Punta & $\mathrm{ctm} . \mathrm{S} / / \mathrm{kW} \cdot \mathrm{h}$ & 23.70 \\
\hline Cargo por Energia Activa Fuera de Punta & $\mathrm{ctm} . \mathrm{S} / / \mathrm{kW} \cdot \mathrm{h}$ & 19.89 \\
\hline \multicolumn{3}{|l|}{ Cargo por Potencia Activa de generacón para Usuarios: } \\
\hline Presentes en Punta & $\mathrm{S} / / \mathrm{kW}$-mes & 45.43 \\
\hline Presentes Fuera de Punta & $\mathrm{S} / / \mathrm{kW}$-mes & 24.21 \\
\hline \multicolumn{3}{|l|}{ Cargo por Potencia Activa de redes de distribución para Usuarios: } \\
\hline Presentes en Punta & $\mathrm{S} / / / \mathrm{kW}-\mathrm{mes}$ & 11.76 \\
\hline Presentes Fuera de Punta & $\mathrm{S} / \sqrt{ } \mathrm{kW}$-mes & 11.24 \\
\hline Cargo por Energia Reactiva que exceda el $30 \%$ del total de la Energia Activa & $\mathrm{ctm} . \mathrm{S} / / \mathrm{kVVar} \cdot \mathrm{h}$ & 4.61 \\
\hline
\end{tabular}

\section{CONCLUSIONS}

The concept of Cleaner Production can be applied to the case of a university campus, considering it a part of the services sector, looking for opportunities to improve environmental aspects and, at the same time, obtaining economic benefits for the university.

A university campus, as a study subject, consists of inputs, operations, and outputs, which can be quantified and optimized according to technological, economic and/or environmental criteria.

The university campus consists of schools and departments, in which important uses and consumption of electricity, fuels, water, and paper, among others, are observed.

The methodology elaborated for implementation of a Cleaner Production program in a university campus consists of five general steps: 1) Planning and Organization, 2) Diagnostic, 3) Feasibility Study, 4) Implementation and Follow-Up, and 5) Continuous Improvement.

$17^{\text {th }}$ LACCEI International Multi-Conference for Engineering, Education, and Technology: "Industry, Innovation, And Infrastructure for Sustainable Cities and Communities", 24-26 July 2019, Jamaica. 
It is necessary to involve and obtain the commitment of university authorities. This implies to make available material, human, and financial resources in order to achieve target objectives. With regard to that, authorities should be informed about the benefits that can be obtained through a Cleaner Production program.

It is quite important to carry out a diagnostic in order to develop technical and financial foundations for the program. In general, it is conducted by an external consulting team, who are experts in Cleaner Production, in the fields of energy savings and pollution prevention, and it is supported by a Cleaner Production committee.

For each one of the opportunities selected during the diagnostic, it should be determined the required evaluation (technical, economic, and/or environmental) in order to make a decision about its feasibility, and the depth in which the required evaluations will be carried out.

In order to assure that implementation of the opportunities might be carried out in a logical and a programmed way, a detailed action plan should be prepared.

Cleaner Production philosophy is considered as a continuous improvement program that has as a primary objective to reduce constantly emissions, waste, effluents, raw material and energy consumption in the university campus.

The proposed methodology can be supplemented with International Standard ISO 50001, which is oriented to reduce both carbon emissions and energy consumption.

\section{REFERENCES}

[1] INACAL, "Guía de Producción Más Limpia", 2007.

[2] INACAL, "Auditoría de Producción Más Limpia”, 2008.

[3] UNIDO, "Cleaner Production Educational Package", 2016.

[4] Ministry of Environment, "Guía de Eco-eficiencia en Edificios Públicos", 2009.

[5] US Department of Energy, "Industrial Asssessment Centers - Program Report", 2015.

[6] INACAL, "Energy Management Systems ISO 50001”, 2012.

$17^{\text {th }}$ LACCEI International Multi-Conference for Engineering, Education, and Technology: "Industry, Innovation, And Infrastructure for Sustainable Cities and Communities", 24-26 July 2019, Jamaica. 